\title{
A brief review: the prevalence of tick-borne pathogens in urban and suburban areas
}

\section{Justina Snegiriovaitė,}

Jana Radzijevskaja ${ }^{*}$,

Algimantas Paulauskas

Vytautas Magnus University,

K. Donelaičio g. 58,

44248 Kaunas, Lithuania
Ticks are widely distributed blood-sucking ectoparasites and vectors for numerous zoonotic pathogens that cause infectious diseases in humans and animals. The increase in the incidence of tick-borne diseases (TBD) is partially associated with climatic changes, such as shorter and warmer winters, prolonged growing seasons, and also with increasing urbanisation. In recent decades, a rising number of established populations of medically important ticks have been reported in urban and suburban areas such as city parks or suburban forests over many regions in Europe. The transformation of natural ecosystems into urban areas becomes actual significant problem because it could affect the circulation of tick-borne pathogens and increase the risk of infection for humans and domestic animals. Tick-borne pathogens, including Borrelia burgdorferi s. 1., Rickettsia spp., Anaplasma phagocytophilum, Candidatus Neoehrlichia mikurensis, and Babesia spp., have been detected in urban tick populations in Europe. Such places as parks, leisure-time areas, green spaces, and gardens become endemic zones of tick-borne pathogens. This review describes the investigations on the prevalence of tick-borne pathogens in urbanised areas conducted in Europe during the last fifteen years (2005-2020).

Keywords: ticks, tick-borne pathogens, urban and suburban habitats

\section{INTRODUCTION}

Vector-borne diseases are one of the most important public health problems of the 21st century, which is increasing all over the world. At present, vector-borne diseases comprise a large group of worldwide diseases caused by arthropods, such as ticks, fleas, mosquitoes, and others. In Europe, one of the most well-known and widely distributed tick species is Ixodes ricinus. This tick is the major vector for a number of pathogens (tick-borne

\footnotetext{
*Corresponding author. Email: jana.radzijevskaja@vdu.lt
}

encephalitis virus, Borrelia burgdorferi sensu lato, Borrelia miyamotoi, Rickettsia spp., Anaplasma phagocytophilum, Babesia divergens, Babesia microti, and others) and parasitizes a wide range of mammals, including the human (Parola, Raoult, 2001; Gray, 2002; García-Álvarez et al., 2013).

The increase in the incidence of tick-borne diseases (TBD) is associated with climatic changes, such as shorter and warmer winters, prolonged growing seasons, and also with rapid urbanisation. The transformation of natural ecosystems into urban areas becomes an major problem because it could affect the circulation of tick-borne pathogens 
and increase the risk of infection for humans and domestic animals. In recent decades, a rising number of established populations of medically important ticks have been reported in urban and suburban areas over many European regions. Environmental changes and the urbanisation process increase the exposure of the human population to ticks. Due to the increased risk of tick bites, it is necessary to investigate the prevalence of tick-borne infections in ticks from urban and suburban areas (Grochowska et al., 2020). Usually, the various types of developed human settlements are divided into urban, suburban, and rural. An urban area is a region surrounding a city. It can be characterised as areas with a high density of human population and infrastructure of the built environment and contains no rural land. Urban habitats comprise public parks, city forests, and green areas used for recreational activities and highly frequented by people. Suburban areas are zones of lower population density located near cities. Suburban areas have greater natural diversity. There are represented by gardens, long-distance footpaths, and leisure-time areas for hiking, biking, and horse riding. Finally, rural areas are located outside towns and cities dominated by the natural environment and the presence of farming or forestry. Suburban and rural areas are rich in species of wild animals (large and small mammals, and birds). It should be noted that some species of mammals and birds are the main hosts of ticks and reservoirs for tick-borne pathogens. In urbanised areas, wild animals and their ectoparasites adapt to the new environment, and ticks are an example of species that well adapt to new conditions. For this reason, the diversity and number of wildlife ectoparasites and pathogens transmitted by them in urbanised areas may increase (Pfäffle et al., 2013; Rizzoli et al., 2014). Several reports indicate that ticks are well adapted to urban and suburban environments (reviewed in Michalski et al., 2020).

An opinion still exists that the major risk of ticks and tick-borne diseases is associated with wooded and high grass areas. However, in recent decades, more reports have appeared which focus on tick and tick-borne infections in urban and suburban landscapes (Akimov, Nebogatkin, 2016). It is not surprising, because currently more than half of the world's population lives in urban areas; hencepublic parks, gardens, and leisure-time areas have become particularly important places where humans and domestic animals can encounter potentially infected questing ticks.

Despite the growing interest in the study of ticks in cities, the prevalence of tick-borne pathogens in urban and suburban areas is still not well known. In Europe, populations of urban ticks and pathogens transmitted by them were studied in Germany, Poland, Slovakia, the Czech Republic, Switzerland, Finland, and Italy (Table). This review describes the prevalence of tick-borne pathogens isolated from

Table. The occurrence of tick-borne pathogens in questing ticks in urban and suburban areas in Europe

\begin{tabular}{|c|c|c|c|c|}
\hline $\begin{array}{l}\text { Locali- } \\
\text { ties }\end{array}$ & Habitat & Pathogenic agent & $\begin{array}{l}\text { Preva- } \\
\text { lence, } \%\end{array}$ & References \\
\hline \multirow{3}{*}{$\begin{array}{l}\text { Czech } \\
\text { Repub- } \\
\text { lic }\end{array}$} & \multirow{3}{*}{$\begin{array}{l}\text { urban forest, } \\
\text { park, subur- } \\
\text { ban area }\end{array}$} & B. burgdorferi s. 1 . & $17.3 \%$ & \multirow{3}{*}{$\begin{array}{c}\text { Venclikova et al., } \\
\text { 2015; Kybico- } \\
\text { va et al., } 2017\end{array}$} \\
\hline & & A. phagocytophilum & $4.4 \%$ & \\
\hline & & Babesia spp. & $0 \%$ & \\
\hline \multirow{5}{*}{ Finland } & \multirow{5}{*}{$\begin{array}{c}\text { urban city } \\
\text { parks, yards, } \\
\text { vegetation- } \\
\text { flanked walk- } \\
\text { ways, green } \\
\text { public spaces }\end{array}$} & $\begin{array}{c}\text { Borrelia spp. (B. afzelii, B. garinii, B. val- } \\
\text { aisiana, B. burgdorferi s. s.) }\end{array}$ & $\begin{array}{l}18.9- \\
23.0 \% \\
\end{array}$ & \multirow{5}{*}{$\begin{array}{l}\text { Sormunen et al., } \\
\text { 2016, 2020; Klemo- } \\
\text { la et al., } 2019\end{array}$} \\
\hline & & A. phagocytophilum & $1.1-5.1 \%$ & \\
\hline & & Rickettsia spp. (R. helvetica; R. monacensis) & $7.9-16.2 \%$ & \\
\hline & & C. N. mikurensis & $1.0-2.5 \%$ & \\
\hline & & Babesia spp. (B. venatorum; B. capreoli) & $0.4-1.4 \%$ & \\
\hline
\end{tabular}


Table. (Continued)

\begin{tabular}{|c|c|c|c|c|}
\hline $\begin{array}{l}\text { Locali- } \\
\text { ties }\end{array}$ & Habitat & Pathogenic agent & $\begin{array}{l}\text { Preva- } \\
\text { lence, } \%\end{array}$ & References \\
\hline \multirow{4}{*}{$\begin{array}{l}\text { Ger- } \\
\text { many }\end{array}$} & \multirow{4}{*}{$\begin{array}{c}\text { city parks, } \\
\text { gardens, urban } \\
\text { woodland, } \\
\text { public recre- } \\
\text { ation areas }\end{array}$} & $\begin{array}{l}\text { Borrelia spp. (B. garinii/B. bavariensis; } \\
\text { B. afzelii; B. valaisiana; B. burgdorferi s. s.; } \\
\text { B. spielmanii; B. bissettii; B. lusitaniae) }\end{array}$ & $\begin{array}{l}24.1- \\
34.1 \%\end{array}$ & \multirow{4}{*}{$\begin{array}{l}\text { Schorn et al., 2011; } \\
\text { Silaghi et al., 2012; } \\
\text { Overzier et al., } \\
\text { 2013a, 2013b; } \\
\text { May et al., 2015; } \\
\text { Blazejak et al., 2017, } \\
2018\end{array}$} \\
\hline & & A. phagocytophilum & $1.7-7.4 \%$ & \\
\hline & & Rickettsia spp. & $22.9-$ & \\
\hline & & $\begin{array}{c}\text { Babesia spp. (B. venatorum, B. microti, } \\
\text { B. capreoli, B. divergens, B. gibsoni) }\end{array}$ & $0.3-3.4 \%$ & \\
\hline \multirow{4}{*}{ Italy } & \multirow{4}{*}{ Urban park } & B. burgdorferi s. 1. & $26.7-36 \%$ & \multirow{4}{*}{$\begin{array}{c}\text { Mancini et al., 2014; } \\
\text { Aureli et al., } 2015\end{array}$} \\
\hline & & A. phagocytophilum & $7.9 \%$ & \\
\hline & & Rickettsia spp. & $36.0 \%$ & \\
\hline & & B. microti & $4.0 \%$ & \\
\hline \multirow{3}{*}{$\begin{array}{l}\text { Lithu- } \\
\text { ania }\end{array}$} & \multirow{3}{*}{ Urban parks } & B. burgdorferi s. 1. (B. garinii; B. afzelii) & $25.0 \%$ & \multirow{3}{*}{$\begin{array}{l}\text { Žygutienè et al., } \\
2008\end{array}$} \\
\hline & & A. phagocytophilum & $0 \%$ & \\
\hline & & Babesia microti & $0 \%$ & \\
\hline \multirow{5}{*}{ Poland } & \multirow{5}{*}{$\begin{array}{l}\text { Urban parks, } \\
\text { forest, }\end{array}$} & $\begin{array}{c}\text { Borrelia spp. (B. afzelii, B. burgdorferi, } \\
\text { B. garinii, B. lusitaniae, B. spielmani and } \\
\text { B. valaisiana) }\end{array}$ & $11-27.4 \%$ & \multirow{5}{*}{$\begin{array}{l}\text { Welc-Falęciak et al., } \\
\text { 2012, 2014; Stanc- } \\
\text { zak et al., 2015; } \\
\text { Kowalec et al., 2017, } \\
\text { 2019; Kubiak et al., } \\
2019\end{array}$} \\
\hline & & A. phagocytophilum & $3-5.3 \%$ & \\
\hline & & Rickettsia spp. (R. helvetica; R. monacensis) & $6.5-7.7 \%$ & \\
\hline & & Ca. N. Mikurensis & $0-0.5 \%$ & \\
\hline & & Babesia spp. (B. venatorum, B. canis) & $0.6-4.5 \%$ & \\
\hline \multirow{5}{*}{ Slovakia } & \multirow{5}{*}{$\begin{array}{l}\text { Suburban, } \\
\text { urban forests, } \\
\text { urban parks, } \\
\text { cementaries }\end{array}$} & $\begin{array}{c}\text { Borrelia spp. (B. afzelii, B. garinii, B. burg- } \\
\text { dorferi s. s., B. valaisiana, B. spielmanii) }\end{array}$ & $\begin{array}{c}6.8- \\
10.15 \%\end{array}$ & \multirow{5}{*}{$\begin{array}{c}\text { Pangrácová et al., } \\
\text { 2013; Špitalská et al., } \\
\text { 2014; } \\
\text { Svitálková et al., } \\
\text { 2015; } \\
\text { Hamšíková et al., } \\
\text { 2016; Mini- } \\
\text { chová et al., 2017; } \\
\text { Chvostáč et al., } 2018\end{array}$} \\
\hline & & A. phagocytophilum & $2.69-5.9 \%$ & \\
\hline & & Rickettsia spp. (R. helvetica, R. monacensis) & $0.2-13.3 \%$ & \\
\hline & & Ca. N. Mikurensis & $2.39 \%$ & \\
\hline & & Babesia spp. & $1.2 \%$ & \\
\hline \multirow{5}{*}{$\begin{array}{l}\text { Switzer- } \\
\text { land }\end{array}$} & \multirow{5}{*}{$\begin{array}{l}\text { urban parks, } \\
\text { river sides, } \\
\text { cemeteries, } \\
\text { suburban } \\
\text { forests, areas }\end{array}$} & $\begin{array}{c}\text { Borrelia spp. (B. afzelii, B. burgdorferi s. s., } \\
\text { B. garinii, B. valaisiana, B. miyamotoi) }\end{array}$ & $18.0 \%$ & \multirow{5}{*}{ Oechslin et al., 2017} \\
\hline & & A. phagocytophilum & $1.4 \%$ & \\
\hline & & Rickettsia spp. (R. helvetica, R. monacensis) & $13.5 \%$ & \\
\hline & & Ca. N. Mikurensis & $6.2 \%$ & \\
\hline & & B. venatorum & $0.8 \%$ & \\
\hline
\end{tabular}


ticks in urbanised areas that can potentially cause diseases in humans and domestic animals in Europe based on the data reported in the literature from 2005 to 2020 .

\section{PATHOGENS OF MEDICAL AND VETERI- NARY IMPORTANCE TRANSMITTED BY TICKS IN URBAN AND SUBURBAN AREAS}

I. In Europe, Lyme borreliosis is the most commonly diagnosed and widely known systemic infectious disease caused by the spirochetes of Borrelia burgdorferi sensu lato (s. 1.) complex (now comprising about 20 named and proposed genospecies) transmitted by Ixodidae ticks (Casjens et al., 2011; Becke et al., 2016). The main vectors of $B$. burgdorferi s. l. in Europe are two tick species from the genus Ixodes: I. ricinus and I. persulcatus. Nine of B. burgdorferi s. l. genospecies have been detected in European I. ricinus ticks (Rauter, Hartung, 2005). In Europe, B. afzelii, B. garinii, B. burgdorferi s. s., B. valaisiana, and $B$. lusitaniae are the most common of them. Genospecies commonly associated with localised, disseminated, and chronic manifestations of Lyme borreliosis are B. afzelii, B. burgdorferi s. s., and B. garinii (Tilly et al., 2008; Rizzoli et al., 2011; Kowalec et al., 2017).

Frequently, most ticks become infected with Borrelia during their larval feeding on infected hosts (Tilly et al., 2008), but if a tick is infected with Borrelia at the larval stage, it will be infected at all other stages of its development due to transstadial transmission of bacteria. Studies conducted in Europe have demonstrated that $B$. burgdorferi s. 1 . infection in I. ricinus ticks collected in urban parks, gardens, or suburban habitats is distributed approximately at the same rate as in I. ricinus collected in forests. In Poland, no significant differences in the prevalence of Borrelia spp. between urban and natural areas was detected and the risk factors of borreliosis appear to be similar in urban and natural areas, in cities and endemic forest areas (Kowalec et al., 2017). Authors detected six species of bacteria present in both types of areas, with different frequencies: $B$. afzelii was the dominant species in urban areas, and B. garinii in natural areas (Kowalec et al., 2017). In Finland, the most common pathogens detected in the $I$. ricinus populations in urban areas belong to the $B$. burgdorferi s. l. complex represented by B. afzelii, B. garinii, and B. burgdorferi s. s. (Klemola et al., 2019; Sormunen et al., 2020). The authors' findings demonstrated that the prevalence and diversity of tick-borne pathogens in urban areas were comparable to those found in natural areas. Borrelia spp. infection in ticks in urban areas range from $17.9 \%$ to $24.4 \%$ in Germany (Maetzel et al., 2005; Tappe et al., 2014; May et al., 2015; Blazejak et al., 2018), from $22 \%$ to $26.7 \%$ in Italy (Mancini et al., 2014; Aureli et al., 2015), and reach 18.0\% in suburban areas in Switzerland (Oechslin et al., 2017). The prevalence of B. burgdorferi s. 1 . in urban and suburban forests was recorded to reach $20.5 \%$ across various cities in Slovakia. The authors detected the presence of six species with the dominance of $B$. afzelii, B. garinii, $B$. burgdorferi s. s. and B. valaisiana (Pangrácová et al., 2013; Chvostáč et al., 2018).

B. afzelii and B. garinii species are frequently detected in ticks in inhabited urban and suburban environments. It has been shown that the presence of different B. burgdorferi s. 1. pathogens in ticks is correlated with the abundance of reservoir hosts in urban areas (Chvostáč et al., 2018). Small rodents (especially Apodemus spp., Microtus spp., and Myodes glareolus) are regarded as the most important hosts for the maintenance of immature stages of I. ricinus and the main reservoir hosts for Lyme borreliosis pathogens such as B. afzelii, B. bavariensis, B. burgdorferi s. s., and $B$. spielmanii in urban and suburban habitats across Europe. Rats (Ratus norvegicus and $R$. rattus) can also play an important role in the urban maintenance of B. afzelii and B. spielmanii. B. afzelii B. burgdorferi s. s. and B. spielmanii can also be maintained in hedgehogs (Erinaceus europaeus and E. roumanicus) and red squirrels (Sciurus vulgaris) (which are usually heavily infested by ticks), especially in urban areas (reviewed in Rizzoli et al., 2014, Chvostáč et al., 2018). Birds, especially ground-foraging bird species (such as common blackbird Turdus merula, song thrush 
T. philomelos, and European robin Erithacus rubecula) play an important role in the epidemiology of Lyme borreliosis and are associated with transmission of $B$. garinii and B. valaisiana to ticks in urban and suburban areas (reviewed in Rizzoli et al., 2014). Consequently, birds, rodents, and other mammals create suitable conditions for the spread of Borrelia pathogens transmitted by ticks in both natural habitats and urban areas.

Several studies in Lithuania have addressed the prevalence of Borrelia burgdorferi s. 1 . in questing ticks and ticks collected from their animal hosts (Turčinavičienė et al., 2006; Paulauskas et al., 2008; Žèkienè et al., 2011; Radzijevskaja et al., 2013) in different natural habitats. These studies demonstrated that the prevalence of Borrelia burgdorferi s. 1 . in questing I. ricinus ticks varied locally from $1.6 \%$ to $29.2 \%$ and among different habitat types (from $8.6 \%$ in pine forests to $19.4 \%$ in deciduous and mixed forests). Only one study, by Žygutienė et al. (2008), reported the prevalence of Borrelia burgdorferi s. 1 . pathogens in ticks collected in urban habitats in Lithuania. During this study, 36 adult I. ricinus ticks were collected in two city parks in the centre of Vilnius, and, despite the small sample size, several important tick-borne pathogens, $B$. afzelii, and B. garinii among them, were detected. The authors concluded that people visiting these parks were exposed to the risk of tick-borne infection transmitted by ticks, especially when resting on the grass (Žygutienè et al., 2008). However, further investigations are necessary to assess the risk of Borrelia infection in non-urban areas in Lithuania.

II. Anaplasma phagocytophilum is small gram-negative intracellular bacterium, which is the main agent causing tick-borne disease such as granulocytic anaplasmosis in humans (HGA) and animals (Dumler et al., 2006; Nicholson et al., 2010). A. phagocytophilum is wide distributed across Europe, Asia and the USA (Carlyon et al., 2003; Stuen et al., 2013). Clinical manifestations of $A$. phagocytophilum infection range from non-specific influenza-like symptoms with fever, headache, myalgia, leukopenia, thrombocytopenia, to fatal infections for pa- tients. This bacterium is transmitted via a bite of tick of the genus Ixodes and infects a variety of animals, including ruminants, rodents, insectivores, birds and reptiles. A. phagocytophilum can also cause disease in pets, commonly in dogs. A wide range of A. phagocytophilum seroprevalence in dogs was determined: $43 \%$ in Germany (Jensen et al., 2007; Kohn et al., 2011), 11-12\% in Latvia (Berzina et al., 2013), and 17\% in Poland (Dzięgiel et al., 2017). It is suspected that the prevalence of infection in dogs is related to the distribution and seasonality of ticks (Carrade et al., 2009; Berzina et al., 2013). A. phagocytophilum was also detected in ticks collected from dogs in urban areas in Poland (Michalski et al., 2020).

The infection rate of $A$. phagocytophilum in ticks collected in urban and suburban areas in Slovakia, Switzerland, Poland, Germany, the Czech Republic, and Italy was found less than $10 \%$. In Switzerland, the infection rate of I. ricinus by $A$. phagocytophilum in urban parks and forests, suburban forests, and cemeteries was $1.4 \%$ (Oechslin et al., 2017). In Slovakia, the prevalence of $A$. phagocytophilum was significantly higher in ticks collected in the urban/ suburban habitats $(7.2 \%)$ compared to that in the natural habitat (3.1\%) (Svitálková et al., 2015). Similar findings come from Germany, where the prevalence of $A$. phagocytophilum in questing $I$. ricinus was $4.9-7.4 \%$ in urban areas, $1.1-2.8 \%$ in pasture, and $4.0-5.8 \%$ in natural areas (Overzier et al., 2013). In Poland, the prevalence of infection in urban sites (3\%) was almost three times higher than in natural sites (1.1\%) (Welc-Falęciak et al., 2014). In Europe, A. phagocytophilum consists of two genetically distinct ecotypes that circulate in two enzootic cycles: one involving rodents and Ixodes trianguliceps ticks and the other involving ungulates, carnivores, insectivores, and I. ricinus ticks (Bown et al., 2009; Blanarova et al., 2014). Thus, I. ricinus ticks could not acquire A. phagocytophilum while feeding on infected rodents. In recent study performed in Slovakia, A. phagocytophilum was detected in $5.9 \%$ of questing I. ricinus ticks collected in urban forested areas. Pathogen prevalence was significantly higher 
compared with A. phagocytophilum prevalence previously detected in various urban and sylvatic habitats in Slovakia (rewied in Chvostáč et al., 2018). The authors suggested that a higher infection rate may have been affected by the presence of roe deer and hedgehogs, the main reservoir hosts of $A$. phagocytophilum strains specific for I. ricinus, in the study area (Chvostáč et al., 2018). In Italy, where ticks were collected from three parks, I. ricinus was the only species found positive for A. phagocytophilum infection with prevalece 7.9\% (Aureli et al., 2015). In the Czech Republic, comparing only the data of spring season, the highest prevalence of Anaplasma (8.6\%) infection was found in the urban park, while the prevalences detected in rural and mountain locations were lower $(0.8 \%$ and $1.6 \%$, respectively) (Kybicová et al., 2017). It could be concluded that infection risks associated with the presence of Anaplasma in ticks in urban areas may be comparable to or even higher than those in natural ecosystems.

In Lithuania, A. phagocytophilum was detected in questing $I$. ricinus and $D$. reticulatus ticks with prevalence of $2.9 \%$ and $8 \%$, respectively (Paulauskas et al., 2012). Using real-time PCR analysis, A. phagocytophilum DNAwas also detected in $35.0 \%$ of dogs presented in veterinary clinics in Lithuanian cities (Radzijevskaja et al., 2020).

III. Candidatus Neoehrlichia mikurensis, the recently emerging pathogen, is a small, gram-negative, pleomorphic bacteria of the Anaplasmataceae family, which causes neoehrlichiosis, a severe systemic inflammatory syndrome (Kawahara et al., 2004; Silaghi et al., 2015). Ca. N. mikurensis was first identified as a human pathogen in 2010 (Welinder-Olsson et al., 2010). This pathogen was added to the list of tick-borne pathogens that cause human diseases in Europe. The main vector of 'Ca. N. mikurensis' is I. ricinus, and rodents act as reservoir hosts. Ca. N. mikurensis has been detected in I. ricinus ticks from many European countries (including the Baltic countries) with prevalence ranging between $1 \%$ and $11 \%$, and in ticks collected from wild and domestic vertebrates (Rizzoli et al., 2014; Portillo et al.,
2018). However, very few reports on the prevalence of $\mathrm{Ca}$. N. mikurensis in I. ricinus ticks in European urban areas were found. In Slovakia, the rate of infection with $\mathrm{Ca}$. N. mikurensis in urban and suburban areas varied from $0.1 \%$ to 2.7\% (Pangrácová et al., 2013; Derdáková et al., 2014; Svitálková et al., 2016). A similar infection rate was detected in I. ricinus in urbanised areas in Finland (0-2.5\%) (Sormunen et al., 2016; Klemola et al., 2019; Sormunen et al., 2020) and in Poland ( $0 \%$ to $0.5 \%$ ) (Welc-Falęciak et al., 2014). In Switzerland, however, the infection rate in urban areas was much higher (6.2-6.4\%) (Lommano et al., 2012; Oechslin et al., 2017). In Slovakia, the prevalence of Ca. N. mikurensis in urban and natural habitats differed significantly: in natural areas, the percentage of $\mathrm{Ca}$. N. mikurensis-positive ticks and rodents was significantly higher than in urban areas (Svitálková et al., 2016). Ca. N. mikurensis is an emerging pathogen that might be found in increasing numbers in ticks from urban sites, in small mammals, and humans in future (Rizzoli et al., 2014).

IV. Rickettsia (family Rickettsiaceae; order Rickettsiales), which is the causative agent of human rickettsiosis, is a gram-negative, obligate, intracellular bacterium transmitted by ticks, mites, fleas, and lice (Raoult, Roux, 1997). Rickettsioses are associated with hard ticks belonging to the Spotted Fever (SF) rickettsiae, with the exception of Rickettsia akari (miteborne) and R. felis (flea-borne) (Rizzoli et al., 2014). The presence of tick-borne rickettsiae has been reported from almost all European countries. Ixodidae ticks can transmit these bacteria transstadially and transovarially and serve both as vectors and reservoirs of these pathogens (Raoult, Roux, 1997; Murray et al., 2016). I. ricinus and Dermacentor spp. are the most important hard tick species in Europe, which are implicated in the transmission of tick-borne rickettsiae. The tick $I$. ricinus is the main vector of $R$. helvetica and R. monacensis, while R. raoultii and R. slovaca are commonly found in D. reticulatus and D. marginatus (Parola et al., 2013). Small rodents, which are the main hosts for immature stages of ixodid ticks, are suspected to serve as reservoirs of rickettsiae (Parola et al., 
2013; Obiegala et al., 2017). In Europe, $R$. helvetica, $R$. raoultii, and $R$. slovaca have been detected in rodents (Martello et al., 2013; Minichová et al., 2014; Obiegala et al., 2016, 2017; Mardosaitè-Busaitienè et al., 2018). Different species of rodents could also play an important role in the urban maintenance of ticks and Rickettsia pathogens.

In Europe, the prevalence of Rickettsia in ticks varies greatly, from $0.5 \%$ to even $66 \%$, depending on the study location (reviewed in Rizzoli et al., 2014). Several studies conducted in Europe have investigated the prevalence of Rickettsia spp. in tick populations in urbanised areas. In Poland, where the relatively low overall prevalence of infection with Rickettsia spp. in ticks was detected (4.4\%; 5.6\%), more ticks were infected with these bacteria in urban areas $(6.5 \% ; 7.7 \%)$ than in natural areas $(2.9 \% ; 4.4 \%)$ (Welc-Falęciak et al., 2014; Kowalec et al., 2019). Similar infection prevalence was reported in recreational sites in the urban areas of Bavaria in Germany (6.4-7.7\%), Bratislava (7.8\%), Paris $(5.8 \%)$, Slovakia $(6.6 \%)$, and Finland (7.910.2\%) (Schorn et al., 2011; Kowalec et al., 2019; Klemola et al., 2019; Sormunen et al., 2020). In Slovakia, where the presence of Rickettsia spp. was examined in different species of Ixodidae ticks collected in different habitat types, the prevalence of infection in questing I. ricinus ticks from suburban, natural, and rural habitats was $6.6 \%, 7.2 \%$, and $2.8 \%$, respectively, while in D. marginatus ticks, Rickettsia spp. were detected only in rural habitats with prevalence $21.4 \%$ (Špitalská et al., 2014; Minichová et al., 2017). Authors detected dominance of I. ricinus across all study sites, and the highest diversity of tick species in the rural habitat, where D. marginatus, Haemaphysalis concinna and Haemaphysalis inermis were found in addition to the dominant I. ricinus (Minichová et al., 2017).

In all reviewed studies, the dominant species detected in I. ricinus ticks in urban and suburban areas was R. helvetica, whereas R. monasensis was detected with much lower prevalence (Kowalec et al., 2019). R. slovaca and R. raoultii were identified in D. marginatus (Minichová et al., 2017).
Blazejak et al. (2017) showed significantly increased infection rate with Rickettsia spp. in tick population during a 10-year period: from $33.3 \%$ in 2005 and $26.2 \%$ in 2010 to $50.8 \%$ in 2015. This is one of examples of how the spread of pathogens can change over the years.

In Lithuania, the prevalence of Rickettsia spp. was investigated in I. ricinus and D. reticulatus ticks and in different species of small mammals in natural habitats (Radzijevskaja et al., 2008; Mardosaité-Busaitienè et al., 2018; Radzijevskaja et al., 2015). The prevalence of Rickettsia spp. in questing D. reticulatus and I. ricinus was $4.9 \%$ and $17 \%$, respectively. The overall prevalence detected in small mammals was $27.6 \%$.

Different species of tick hosts presented in city parks and small urban forests, large human population, and increasing transformation of the natural environment provide ideal conditions for the circulation and spread of tickborne Rickettsia spp. (Rizzoli et al., 2014).

V. Babesiosis, which is caused by different intraerythrocytic protozoan Babesia parasites, is recognized as an important tick-borne infectious disease in humans and animals. Babesia spp. are considered to be emerging pathogens in Europe that circulate in a natural tick-reservoir host cycle and is usually transmitted to humans, wild and domestic animals through the bite of an infected tick. In Europe, I. ricinus tick is the main vector of the Babesia species (B. divergens, B. venatorum, and B. microti) causing human babesiosis (Hildebrandt et al., 2013). B. divergens is the most widespread and pathogenic Babesia species infecting cattle in northern temperate areas. D. reticulatus has been recognized as the most important vector of B. canis, the causative agent of canine babesiosis for dogs in Europe (Schaarschmidt et al., 2013; Solano-Gallego et al., 2016). Over the last decades, spread of canine babesiosis due to $B$. canis to the previously non-endemic areas has been reported in Europe (Solano-Gallego, Baneth, 2011). Previous studies conducted in different European countries showed that the prevalence of $B$. canis in adult $D$. reticulatus varies from $0 \%$ to $14.8 \%$. Thus, any urban or suburban area where cattle, dogs, and I. ricinus and 
D. reticulatus ticks are found is potentially at risk. The reservoir hosts of Babesia spp. varied from small mammals (B. microti) to medium and large mammals, such as dogs (B. canis), cattles, and cervids (B. divergens and B. capreoli) (Yabsley, Shock, 2012; Overzier et al., 2013a; Andersson et al., 2016). The prevalence of Babesia spp. in ticks from urban and suburban habitats has been reported in several European countries. In eastern Germany, the prevalence of Babesia spp. in I. ricinus ticks collected in an urban park was found to be $0.4-0.7 \%$. Moreover, most of Babesia-positive ticks were found on sampling sites with permanent population of large mammals (Schorn et al., 2011). In south Germany, I. ricinus infection rate with Babesia spp. in urbanised areas ranged from $0.3 \%$ to 3.4\% (Silaghi et al., 2012; Overzier et al., 2013). The dominant Babesia species found in I. ricinus ticks was $B$. venatorum and B. microti; however, single cases of $B$. capreoli, B. divergens and B. gibsoni were detected. Studies conducted in Belgium, Slovakia, and Finland found similarly low prevalence of Babesia spp. in ticks from urban and suburban areas: $0.2 \%$ (Heylen et al., 2019), 1.2\% (Hamšíková et al., 2016), and 0.4\%, respectively (Sormunen et al., 2020). The highest Babesia spp. infection rate of $4.5 \%$ in urban areas was reported in Poland, and it exceeded the rate in rural areas (2.5\%). B. venatorum (detected in I. ricinus) and B. canis (detected in D. reticulatus) (Stanczak et al., 2015) were the dominant Babesia species in both areas.

In Lithuania, different Babesia spp. have been detected in $I$. ricinus and $D$. reticulatus ticks from various natural habitat types and in city dogs (Paulauskas et al., 2014; Radzijevskaja et al., 2018; Radzijevskaja et al., 2020). Babesia spp. were detected in $1.2 \%(26 / 2259)$ of questing $D$. reticulatus (mostly B. canis, and one case of $B$. venatorum) and in $9.5 \%(35 / 370)$ of $I$. ricinus ticks (represented by B. venatorum, and B. microtii). Although previously uncommon, canine babesiosis has become quite frequent in Lithuania during the past decade and an increasing number of cases with a wide variety of clinical symptoms have been recorded throughout the country. Babesia spp. could be endemic to urban and suburban parks in Lithuania, especially those adjoining more natural or semi-natural areas such as forests or rural areas, and public health risk during recreational activities should be emphasised.

\section{CONCLUSIONS}

This short review surveys studies on the prevalence of tick-borne pathogens Borrelia burgdorferi s. l. complex, Rickettsia spp., Anaplasma phagocytophilum, Candidatus N. mikurensis and Babesia spp. in urbanised areas conducted in Europe during the last 15 years (2005-2020). The presence of these pathogens found in ixodid ticks with the same or higher infection rates than in natural habitats demonstrates that tick-borne diseases are endemic to urban and suburban areas and the potential health risk to humans and domestic animals in these areas should not be underestimated. Variation in the abundance and diversity of tick hosts - medium-sized and small size mammals, groundforaging birds (especially in parks and small urban forests) - has been suggested as a crucial determinant of the prevalence and density of tick-borne pathogens. In urban habitats, humans and their companion animals (mainly dogs), small mammals and birds probably play a significant role as tick hosts and sources of tick-borne pathogens. The presence of large vertebrates (like cervids), which serve as hosts for ticks and as reservoirs of a number of zoonotic pathogens in suburban and rural areas, allows long-term maintenance of the tick population. Urban and suburban areas should be included in surveillance for tick-borne diseases, because the variation of tick density in urbanised areas is clearly unexplained and the risk of pathogens in urban environment needs to be understood. Due to changing environmental conditions, rising abundance of ticks, and diversity of tickborne pathogens, priority should be given to more comprehensive research on ticks and their pathogens in urban areas.

Received 30 October 2020 Accepted 30 November 2020 


\section{References}

1. Akimov I, Nebogatkin IV. Ixodid ticks (Acari, Ixodidae) in urban landscapes. A review. Vestn Zool. 2016; 50: 155-62.

2. Andersson MO, Bergvall UA, Chirico J, Christensson M, Lindgren PE, Nordström J, Kjellander P. Molecular detection of Babesia capreoli and Babesia venatorum in wild Swedish roe deer, Capreolus capreolus. Parasit Vectors. 2016; 9: 221.

3. Aureli S, Galuppi R, Ostanello F, Foley JE, Bonoli C, Rejmanek D, Rocchi G, Orlandi E, Tampieri MP. Abundance of questing ticks and molecular evidence for pathogens in ticks in three parks of Emilia-Romagna region of Northern Italy. Ann Agric Environ Med. 2015; 22(3): 459-66.

4. Becker NS, Margos G, Blum H, Krebs S, Graf A, Lane RS, Castillo-Ramírez S, Sing A, Fingerle V. Recurrent evolution of host and vector association in bacteria of the Borrelia burgdorferi sensu lato species complex. BMC Genomics. 2016; 17(1): 734.

5. Berzina I, Capligina V, Bormane A, Pavulina A, Baumanis V, Ranka R, Granta R, Matise I. Association between Anaplasma phagocytophilum seroprevalence in dogs and distribution of Ixodes ricinus and Ixodes persulcatus ticks in Latvia. Ticks Tick Borne Dis. 2013; 4(1-2): 83-8.

6. Blanarova L, Stanko M, Carpi G, Miklisova D, Vichova B, Mošansky L, Bona M, Derdakova M. Distinct Anaplasma phagocytophilum genotypes associated with Ixodes trianguliceps ticks and rodents in Central Europe. Ticks Tick Borne Dis. 2014; 5(6): 928-38.

7. Blazejak K, Janecek E, Strube C. A 10-year surveillance of Rickettsiales (Rickettsia spp. and Anaplasma phagocytophilum) in the city of Hanover, Germany, reveals Rickettsia spp. as emerging pathogens in ticks. Parasit Vectors. 2017; 10(1): 588 .

8. Blazejak K, Raulf MK, Janecek E, Jordan D, Fingerle V, Strube C. Shifts in Borrelia burg- dorferi (s. 1.) geno-species infections in Ixodes ricinus over a 10 -year surveillance period in the city of Hanover (Germany) and Borrelia miyamotoi-specific Reverse Line Blot detection. Parasit Vectors. 2018; 11: 304.

9. Bown KJ, Lambin X, Ogden NH, Begon M, Telford G, Woldehiwet Z, Birtles RJ. Delineating Anaplasma phagocytophilum ecotypes in coexisting, discrete enzootic cycles. Emerg Infect Dis. 2009; 15: 1948-54.

10. Carlyon JA, Fikrig E. Invasion and survival strategies of Anaplasma phagocytophilum. Cell. Microbiol. 2003; 5: 743-54.

11. Carrade DD, Foley JE, Borjesson DL, Sykes JE. Canine granulocytic anaplasmosis: a review. J Vet Intern Med. 2009; 23(6): 1129-41.

12. Casjens SR, Fraser-Liggett CM, Mongodin EF, Qiu WG, Dunn JJ, Luft BJ, Schutzer SE. Whole genome sequence of an unusual Borrelia burgdorferi sensu lato isolate. J Bacteriol. 2011; 193: 1489-90.

13. Chvostáč M, Špitalská E, Václav R, Vaculová T, Minichová L, Derdáková M. Seasonal patterns in the prevalence and diversity of tick-borne Borrelia burgdorferi sensu lato, Anaplasma phagocytophilum and Rickettsia spp. in an urban temperate forest in South Western Slovakia. Int J Environ Res Public Health. 2018; 15(5): 994.

14. Derdáková $M$, Václav R, Pangrácova-Blaňárová L, Selyemová D, Koči J, Walder G, Špitalská E. Candidatus Neoehrlichia mikurensis and its co-circulation with Anaplasma phagocytophilum in Ixodes ricinus ticks across ecologically different habitats of Central Europe. Parasit Vectors. 2014; 7: 160.

15. Dumler JS, Rikihisa Y, Dasch GA. Family II. Anaplasmataceae. In: Brenner DJ, Krieg NR, Staley JT, editors. Bergey's manual of systematic bacteriology. The Proteobacteria. Part C. New York: Springer-Verlag; 2006. p. 117-20.

16. Dzięgiel B, Adaszek $Ł$, Carbonero A, Łyp P, Winiarczyk M, Dębiak P, Winiarczyk S. Detection of canine vector-borne diseases in eastern Poland by ELISA and PCR. Parasitol Res. 2016; 115(3): 1039-44. 
17. García-Álvarez L, Palomar AM, Oteo JA. Prevention and prophylaxis of tick-bites and tickborne related diseases. Am J Infect Dis. 2013; 9: 104-16.

18. Gray JS. Biology of Ixodes species ticks in relation to tick-borne zoonoses. Wien Klin Wochenschr. 2002; 114(13-14): 473-8.

19. Grochowska A, Milewski R, Pancewicz S, Dunaj J, Czupryna P, Milewska AJ, RógMakal M, Grygorczuk S, Moniuszko-Malinowsk A. Comparison of tick-borne pathogen prevalence in Ixodes ricinus ticks collected in urban areas of Europe. Sci Rep. 2020; 10: 6975.

20. Jensen J, Simon D, Escobar HM, Soller JT, Bullerdiek J, Beelitz P, Pfister K, Nolte I. Anaplasma phagocytophilum in dogs in Germany. Zoonoses Public Health. 2007; 54(2): 94-101.

21. Hajdusek O, Síma R, Ayllón N, Jalovecká M, Perner J, de la Fuente J, Kopáček P. Interaction of the tick immune system with transmitted pathogens. Front Cell Infect Microbiol. 2013; 3: 26.

22. Hamšíková Z, Kazimírová $M$, Haruštiaková $D$, Mahríková L, Slovák M, Berthová L, Kocianová E., Schnittger L. Babesia spp. in ticks and wildlife in different habitat types of Slovakia. Parasit Vectors. 2016; 9(1): 292.

23. Heylen D, Lasters R, Adriaensen F, Fonville M, Sprong H, Matthysen E. Ticks and tick-borne diseases in the city: Role of landscape connectivity and green space characteristics in a metropolitan area. Sci Total Environ. 2019; 670: 941-9.

24. Hildebrandt A, Gray JS, Hunfeld KP. Human babesiosis in Europe: what clinicians need to know. Infection. 2013; 41(6): 1057-72.

25. Yabsley MJ, Shock BC. Natural history of zoonotic babesia: role of wildlife reservoirs. Int J Parasitol Parasites Wildl. 2012; 2: 18-31.

26. Kawahara M, Rikihisa Y, Isogai E., Takahashi M, Misumi $H$, Suto C, Shibata S, Zhang C, Tsuji M. Ultrastructure and phylogenetic analysis of 'Candidatus Neoehrlichia mikurensis' in the family Anaplasmataceae, isolated from wild rats and found in Ixodes ovatus ticks. Int J Syst Evol Microbiol. 2004; 54: 1837-43.

27. Kybicová K, Baštová K, Malý M. Detection of Borrelia burgdorferi sensu lato and Anaplasma phagocytophilum in questing ticks Ixodes ricinus from the Czech Republic. Ticks Tick Borne Dis. 2017; 8(4): 483-7.

28. Klemola T, Sormunen JJ, Mojzer J, Mäkelä S, Vesterinen EJ. High tick abundance and diversity of tick-borne pathogens in a Finnish city. Urban Ecosystems. 2019; 22: 817-26.

29. Kohn B, Silaghi C, Galke D, Arndt G, Pfister K. Infections with Anaplasma phagocytophilum in dogs in Germany. Res Vet Sci. 2011; 91(1): 71-6.

30. Kowalec M, Szewczyk T, Welc-Falęciak R, Siński E, Karbowiak G, Bajer A. Ticks and the city - are there any differences between city parks and natural forests in terms of tick abundance and prevalence of spirochaetes? Parasit Vectors. 2017; 10: 573.

31. Kowalec M, Szewczyk T, Welc-Falęciak R, Siński E, Karbowiak G, Bajer A. Rickettsiales occurrence and co-occurrence in Ixodes ricinus ticks in natural and urban areas. Microb Ecol. 2019; 77(4): 890-904.

32. Krause PJ. Human babesiosis. Int J Parasitol. 2019; 49(2): 165-74.

33. Lommano E, Bertaiola L, Dupasquier C, Gern L. Infections and coinfections of questing Ixodes ricinus ticks by emerging zoonotic pathogens in Western Switzerland. Appl Environ Microbiol. 2012; 78: 4606-12.

34. Maetzel D, Maier WA, Kampen H. Borrelia burgdorferi infection prevalences in questing Ixodes ricinus ticks (Acari: Ixodidae) in urban and suburban Bonn, western Germany. Parasitol Res. 2005; 95: 5-12.

35. May K, Jordan D, Fingerle V, Strube C. Borrelia burgdorferi sensu lato and co-infections with Anaplasma phagocytophilum and Rickettsia spp. in Ixodes ricinus in Hamburg, Germany. Med Vet Entomol. 2015; 29: 425-9. 
36. Mancini F, Di Luca M, Toma L, Vescio F, Bianchi R, Khoury C, Marini L, Rezza G, Ciervo A. Prevalence of tick-borne pathogens in an urban park in Rome, Italy. Ann Agric Environ Med. 2014; 21(4): 723-7.

37. Mardosaitè-Busaitienė D, Radzijevskaja J, Balčiauskas L, Paulauskas A. First detection of Rickettsia helvetica in small mammals in Lithuania. New Microbes New Infect. 2018; 22: 19-23.

38. Martello E, Selmi M, Ragagli C, Ambrogi C, Stella MC, Mannelli A, Tomassone L. Rickettsia slovaca in immature Dermacentor marginatus and tissues from Apodemus spp. in the northern Apennines, Italy. Ticks Tick Borne Dis. 2013; 4: 518-21.

39. Michalski MM, Kubiak K, Szczotko M, Chajęcka M, Dmitryjuk M. Molecular Detection of Borrelia burgdorferi sensu lato and Anaplasma phagocytophilum in ticks collected from dogs in urban areas of North-Eastern Poland. Pathogens. 2020; 9(6): 455.

40. Minichová L, Hamšíková Z, Mahríková L., Slovák M, Kocianová E, Kazimírová M, Škultéty L, Štefanidesová K, Špitalská E. Molecular evidence of Rickettsia spp. in ixodid ticks and rodents in suburban, natural and rural habitats in Slovakia. Parasit Vectors. 2017; 10: 158.

41. Mysterud A, Easterday WR, Qviller L, Viljugrein $\mathrm{H}$, Ytrehus B. Spatial and seasonal variation in the prevalence of Anaplasma phagocytophilum and Borrelia burgdorferi sensu lato in questing Ixodes ricinus ticks in Norway. Parasit Vectors. 2013; 6: 187.

42. Murray GG, Weinert LA, Rhule EL, Welch JJ. The phylogeny of Rickettsia using different evolutionary signatures: how tree-like is bacterial evolution? Syst Biol. 2016; 65: 265-79.

43. Nicholson WL, Allen KE, McQuiston JH, Breitschwerdt EB, Little SE. The increasing recognition of rickettsial pathogens in dogs and people. Trends Parasitol. 2010; 6(4): 205-12.

44. Obiegala A, Oltersdorf C, Silaghi C, Kiefer D, Kiefer M, Woll D, Pfeffer M. Rickettsia spp. in small mammals and their parasitizing ectoparasites from Saxony, Germany. Vet Parasitol Reg Stud Reports. 2016; 5: 19-24.

45. Obiegala A, Król N, Oltersdorf C, Nader J, Pfeffer M. The enzootic life-cycle of Borrelia burgdorferi (sensu lato) and tick-borne rickettsiae: an epidemiological study on wild-living small mammals and their ticks from Saxony, Germany. Parasit Vectors. 2017; 10(1): 115.

46. Oechslin CP, Heutschi D, Lenz N, Tischhauser W, Péter O, Rais O, Beuret CM, Leib SL, Bankoul S, Ackermann-Gäumann R. Prevalence of tick-borne pathogens in questing $I x$ odes ricinus ticks in urban and suburban areas of Switzerland. Parasit Vectors. 2017; 10: 558.

47. Overzier E, Pfister K, Thiel C, Herb I, Mahling M, Silaghi C. Diversity of Babesia and Rickettsia species in questing Ixodes ricinus: a longitudinal study in urban, pasture, and natural habitats. Vector Borne Zoonotic Dis. 2013a; 13(8): 559-64.

48. Overzier E, Pfister K, Thiel C, Herb I, Mahling M, Silaghi C. Anaplasma phagocytophilum in questing Ixodes ricinus ticks: comparison of prevalences and partial 16S rRNA gene variants in urban, pasture, and natural habitats. Appl Environ Microbiol. 2013b; 79(5): 1730-4.

49. Pangrácová L, Derdáková $\mathrm{M}$, Pekárik L, Hviščová I, Víchová B, Stanko M, Hlavatá H, Petko B. Ixodes ricinus abundance and its infection with the tick-borne pathogens in urban and suburban areas of Eastern Slovakia. Parasit Vectors. 2013; 6: 238.

50. Raoult D, Roux V. Rickettsioses as paradigms of new or emerging infectious diseases. Clin Microbiol Rev. 1997; 10: 694-719.

51. Parola P, Paddock CD, Socolovschi C, Labruna MB, Mediannikov O, Kernif T, Abdad MY, Stenos J, Bitam I, Fournier PE, Raoult D. Update on tick-borne rickettsioses around the world: a geographic approach. Clin Microbiol Rev. 201; 26(4): 657-702.

52. Parola P, Raoult D. Ticks and tick-borne bacterial diseases in humans: an emerging infectious threat. Clin Infect Dis. 2001; 32: 897-928. 
53. Paulauskas A, Ambrasienė D, Radzijevskaja J, Rosef $\mathrm{O}$, Turčinavičienè J. Diversity in prevalence and genospecies of Borrelia burgdorferi sensu lato in Ixodes ricinus ticks and rodents in Lithuania and Norway. Int J Med Microbiol. 2008; 298(1): 180-7.

54. Paulauskas A, Radzijevskaja J, Rosef O. Molecular detection and characterization of Anaplasma phagocytophilum strains. Comp Immunol Microbiol Infect Dis. 2012; 35(2): 187-95.

55. Paulauskas A, Radzijevskaja J, Karvelienè B, Grigonis A, Aleksandravičienė A, Zamokas G, Babickaitè L, Sabūnas V, Petkevičius S. Detection and molecular characterization of canine babesiosis causative agent Babesia canis in the naturally infected dog in Lithuania. Vet Parasitol. 2014; 205(3-4): 702-6.

56. Pfäffle M, Littwin N, Muders SV, Petney TN. The ecology of tick-borne diseases. Int J Parasitol. 2013; 43(12-13): 1059-77.

57. Portillo A, Santibáñez P, Palomar AM, Santibáñez S, Oteo JA. 'Candidatus Neoehrlichia mikurensis' in Europe. New Microbes New Infect. 2018 ; 22: 30-6.

58. Radzijevskaja J, Paulauskas A, Rosef O. Prevalence of Anaplasma phagocytophilum and Babesia divergens in Ixodes ricinus ticks from Lithuania and Norway. Int J Med Microbiol. 2008; 298(1): 218-21.

59. Radzijevskaja J, Paulauskas A, Rosef O, Petkevičius S, Mažeika V, Rekašius T. The propensity of voles and mice to transmit Borrelia burgdorferi sensu lato infection to feeding ticks. Vet Parasitol. 2013; 197(1-2): 318-25.

60. Radzijevskaja J, Paulauskas A, Aleksandravičienė A, Jonauskaitė I, Stanko M, Karbowiak G, Petko B. New records of spotted fever group rickettsiae in Baltic region. Microbes Infect. 2015; 17: 874-8.

61. Radzijevskaja J, Mardosaitè-Busaitienè D, Aleksandravičienė A, Paulauskas A. Investigation of Babesia spp. in sympatric populations of Dermacentor reticulatus and Ixodes ricinus ticks in Lithuania and Latvia. Ticks Tick Borne Dis. 2018; 9(2): 270-4.
62. Radzijevskaja J, Tamoliūnaitè D, Sabūnas V, Aleksandravičienė A, Paulauskas A. Prevalence and co-infection of mosquitoand tickborne pathogens in domestic dogs suspected for canine babesiosis in Lithuania. Biologija. 2020; 66(2): 94-102.

63. Rauter C, Hartung T. Prevalence of Borrelia burgdorferi sensu lato genospecies in Ixodes ricinus ticks in Europe: a metaanalysis. Appl Environ Microbiol. 2005; 71(11): 7203-16.

64. Rizzoli A, Hauffe HC, Carpi G, Vourc'h GI, Neteler M, Rosa R. Lyme borreliosis in Europe. Euro Surveill. 2011; 16(27): 19906.

65. Rizzoli A, Silaghi C, Obiegala A, Rudolf I, Hubalek Z, Foldvari G, Plantard O, VayssierTaussat, Bonnet S, Špitalska E, Kazimirova M. Ixodes ricinus and its transmitted pathogens in urban and peri-urban areas in Europe: new hazards and relevance for public health. Front Public Health. 2014; 2: 251.

66. Rosef O, Paulauskas A, Radzijevskaja J. Prevalence of Borrelia burgdorferi sensu lato and Anaplasma phagocytophilum in questing $I x$ odes ricinus ticks in relation to the density of wild cervids. Acta Vet Scand. 2009; 51(1): 47.

67. Schaarschmidt D, Gilli U, Gottstein B, Marreros N, Kuhnert P, Daeppen JA, Rosenberg G, Hirt D, Frey CF. Questing Dermacentor reticulatus harbouring Babesia canis DNA associated with outbreaks of canine babesiosis in the Swiss Midlands. Ticks Tick Borne Dis. 2013; 4(4): 334-40.

68. Schorn S, Pfister K, Reulen H, Mahling M, Silaghi C. Occurrence of Babesia spp., Rickettsia spp. and Bartonella spp. in Ixodes ricinus in Bavarian public parks, Germany. Parasit Vectors. $2011 ; 4: 135$.

69. Silaghi C, Beck R, Oteo JA, Pfeffer M, Sprong H. Neoehrlichiosis: an emerging tickborne zoonosis caused by Candidatus Neoehrlichia mikurensis. Exp Appl Acarol. 2016; 68: 279-97.

70. Silaghi C, Woll D, Hamel D, Pfister K, Mahling M, Pfeffer M. Babesia spp. and Anaplasma phagocytophilum in questing ticks, ticks 
parasitizing rodents and the parasitized rodents - Analyzing the host-pathogen-vector interface in a metropolitan area. Parasit Vectors. 2012; 5(1): 191.

71. Solano-Gallego L, Baneth G. Babesiosis in dogs and cats-Expanding parasitological and clinical spectra. Vet Parasitol. 2011; 181(1): 48-60.

72. Solano-Gallego L, Sainz Á, Roura X, EstradaPeña A, Miró G. A review of canine babesiosis: the European perspective. Parasit Vectors. 2016; 9(1): 336.

73. Sormunen J, Penttinen R, Klemola T, Hänninen J, Vuorinen I, Laaksonen M, Sääksjärvi I, Ruohomäki K, Vesterinen E. Tick-borne bacterial pathogens in Southwestern Finland. Parasit Vectors. 2016; 9: 168.

74. Sormunen JJ, Kulha N, Klemola T, Mäkelä S, Vesilahti EM, Vesterinen EJ. Enhanced threat of tick-borne infections within cities? Assessing public health risks due to ticks in urban green spaces in Helsinki, Finland. Zoonoses Public Health. 2020; 67(7): 822-38.

75. Stańczak J, Cieniuch S, Lass A, Biernat B, Racewicz M. Detection and quantification of Anaplasma phagocytophilum and Babesia spp. in Ixodes ricinus ticks from urban and rural environment, northern Poland, by real-time polymerase chain reaction. Exp Appl Acarol. 2015; 66(1): 63-81.

76. Stuen S, Granquist EG, Silaghi C. Anaplasma phagocytophilum-a widespread multi-host pathogen with highly adaptive strategies. Front Cell Infect Microbiol. 2013; 3: 31.

77. Svitálková Z, Haruštiaková D, Mahríková L, Berthová L, Slovák M, Kocianová E, Kazimírová M. Anaplasma phagocytophilum prevalence in ticks and rodents in an urban and natural habitat in South-Western Slovakia. Parasit Vectors. 2015; 8: 276.

78. Svitálková ZH, Haruštiaková D, Mahríková L, Mojšová M, Berthová L, Slovák M, Kocianová E, Vayssier-Taussat M, Kazimírová M. Candidatus Neoehrlichia mikurensis in ticks and rodents from urban and natural habitats of South-Western Slovakia. Parasit Vectors. 2016; 9: 2.
79. Špitalská E, Boldiš V, Derdáková M, Selyemová D, Rusňáková Taragelová V. Rickettsial infection in Ixodes ricinus ticks in urban and natural habitats of Slovakia. Ticks Tick Borne Dis. 2014; 5(2): 161-5.

80. Tappe J, Jordan D, Janecek E, Fingerle V, Strube C. Borrelia burgdorferi sensu lato infections in hard ticks (Ixodes ricinus) in the city of Hanover (Germany): revisited. Parasit Vectors. 2014; 7: 441.

81. Tilly K, Rosa PA, Stewart PE. Biology of infecttion with Borrelia burgdorferi. Infect Dis Clin North Am. 2008; 22(2): 217-34.

82. Turčinavičienė J, Ambrasienė D, Paulauskas A, Radzijevskaja J, Rosef O, Žygutienè M. The prevalence and distribution of Borrelia burgdorferi sensu lato in host seeking Ixodes ricinus ticks in Lithuania. Biologija. 2006; 1: 64-8.

83. Venclikova K, Mendel J, Betasova L, Hubalek Z, Rudolf I. First evidence of Babesia venatorum and Babesia capreoli in questing Ixodes ricinus ticks in the Czech Republic. Ann Agric Environ Med. 2015; 22(2): 212-4.

84. Žèkienè A, Paulauskas A, Radzijevskaja J, Jusys V. Molecular investigation of tick-borne pathogens in ticks collected on migratory birds in Lithuania. Biologija. 2011; 57(4): 159-65.

85. Žygutienė M, Alekseev A, Dubinina $\mathrm{H}$, Kazlauskien a R. Evidence for a risk of tickborne infection in the city parks of Vilnius, Lithuania. Ekologija. 2008; 54(1): 40-3.

86. Welinder-Olsson C, Kjellin E, Vaht K, Jacobsson S, Wenneras C. First case of human 'Candidatus Neoehrlichia mikurensis' infection in a febrile patient with chronic lymphocytic leukemia. J Clin Microbiol. 2010; 48: 1956-9.

87. Welc-Falęciak R, Bajer A, Paziewska-Harris A, Baumann-Popczyk A, Siński E. Diversity of Babesia in Ixodes ricinus ticks in Poland. Advan Med Sci. 2012; 57: 364-9.

88. Welc-Falęciak R, Kowalec M, Karbowiak G, Bajer A, Behnke JM, Siński E. Rickettsiaceae and Anaplasmataceae infections in Ixodes ricinus ticks from urban and natural forested areas of Poland. Parasit Vectors. 2014; 7: 121. 
Justina Snegiriovaitè, Jana Radzijevskaja, Algimantas Paulauskas

\section{ERKIŲ PERNEŠAMŲ PATOGENŲ PAPLI- TIMAS MIESTUOSE IR PRIEMIESČIUOSE: TRUMPA APŽVALGA}

\section{Santrauka}

Erkès yra plačiai paplitę kraują siurbiantys ektoparazitai ir daugelio zoonozinių patogenų, sukeliančių žmonių ir gyvūnų infekcines ligas, pernešèjai. Erkių platinamų ligų išplitimas siejamas su klimato pokyčiais - trumpesnèmis ir šiltesnèmis žiemomis, užsitęsusia vegetacija bei didèjančia urbanizacija. Pastaraisiais dešimtmečiais daugelyje Europos regionų erkių populiacijos didèja miestų ir priemiesčių teritorijose, pvz., miestų parkuose ar priemiesčių miškuose. Natūralių ekosistemų transformacija i miesto teritorijas gali paveikti erkių platinamų patogenų cirkuliaciją ir padidinti infekcijos riziką žmonèms bei naminiams gyvūnams. Erkių platinami patogenai, i̇skaitant Borrelia burgdorferi s. 1., Rickettsia spp., Anaplasma phagocytophilum, Candidatus Neoehrlichia mikurensis ir Babesia spp., buvo aptikti miesto erkių populiacijose Europoje. Tokios vietos kaip parkai, laisvalaikio praleidimo zonos, žaliosios erdvès, sodai tampa endeminemis erkių platinamų ligų sukèlèjų zonomis. Šioje apžvalgoje aprašomi erkių platinamų patogenų urbanizuotose vietovèse tyrimai, atlikti Europoje per pastaruosius penkiolika metų (2005-2020 m.).

Raktažodžiai: erkès, erkių pernešami patogenai, miesto ir priemiesčio buveinès 